\title{
A one-year economic evaluation of six alternative strategies for the management of uninvestigated upper gastrointestinal symptoms in Canadian primary care
}

\author{
Alan N Barkun MD CM MSc ${ }^{1,2}$, Ralph Crott PhD MPH ${ }^{3}$, Carlo A Fallone MD CMํ․ Wendy A Kennedy PhD MBA LLB ${ }^{4}$ \\ Jean Lachaine PhD BPharm ${ }^{4}$, Carey Levinton MSc, David Armstrong MB BChir MA ${ }^{5}$, Naoki Chiba MD MSc ${ }^{5,6}$, \\ Alan Thomson MD PhD ${ }^{7}$, Sander Veldhuyzen van Zanten MD PhD ${ }^{8}$, Paul Sinclair MSc ${ }^{9}$, Sergio Escobedo MSc ${ }^{10}$, \\ Bijan Chakraborty MStat ${ }^{10}$, Sandra Smyth BSc ${ }^{10}$, Robert White $\mathrm{PhD}^{10}$, Helen Kalra BSc ${ }^{10}$, Krista Nevin $\mathrm{BSc}^{10}$
}

\begin{abstract}
AN Barkun, R Crott, CA Fallone, et al. A one-year economic evaluation of six alternative strategies for the management of uninvestigated upper gastrointestinal symptoms in Canadian primary care. Can J Gastroenterol 2010;24(8):489-498.
\end{abstract}

BACKGROUND: The cost-effectiveness of initial strategies in managing Canadian patients with uninvestigated upper gastrointestinal symptoms remains controversial.

OBJECTIVE: To assess the cost-effectiveness of six management approaches to uninvestigated upper gastrointestinal symptoms in the Canadian setting.

METHODS: The present study analyzed data from four randomized trials assessing homogeneous and complementary populations of Canadian patients with uninvestigated upper gastrointestinal symptoms with comparable outcomes. Symptom-free months, qualityadjusted life-years (QALYs) and direct costs in Canadian dollars of two management approaches based on the Canadian Dyspepsia Working Group (CanDys) Clinical Management Tool, and four additional strategies (two empirical antisecretory agents, and two prompt endoscopy) were examined and compared. Prevalence data, probabilities, utilities and costs were included in a Markov model, while sensitivity analysis used Monte Carlo simulations. Incremental cost-effectiveness ratios and cost-effectiveness acceptability curves were determined.

RESULTS: Empirical omeprazole cost $\$ 226$ per QALY ( $\$ 49$ per symptom-free month) per patient. CanDys omeprazole and endoscopy approaches were more effective than empirical omeprazole, but more costly. Alternatives using $\mathrm{H}_{2}$-receptor antagonists were less effective than those using a proton pump inhibitor. No significant differences were found for most incremental cost-effectiveness ratios. As willingness to pay (WTP) thresholds rose from $\$ 226$ to $\$ 24,000$ per QALY, empirical antisecretory approaches were less likely to be the most costeffective choice, with CanDys omeprazole progressively becoming a more likely option. For WTP values ranging from $\$ 24,000$ to $\$ 70,000$ per QALY, the most clinically relevant range, CanDys omeprazole was the most cost-effective strategy ( $32 \%$ to $46 \%$ of the time), with prompt endoscopy-proton pump inhibitor favoured at higher WTP values.

CONCLUSIONS: Although no strategy was the indisputable costeffective option, CanDys omeprazole may be the strategy of choice over a clinically relevant range of WTP assumptions in the initial management of Canadian patients with uninvestigated dyspepsia.

Key Words: Antisecretory therapy; Cost-effectiveness; Dyspepsia; Economic modelling; Endoscopy; Helicobacter pylori
Évaluation économique d'un an sur six stratégies de prise en charge des symptômes digestifs hauts non investigués en médecine générale au Canada

HISTORIQUE : On ne s'entend toujours pas sur le rapport coût:efficacité des stratégies initiales de prise en charge des patients canadiens présentant des symptômes digestifs hauts non investigués.

OBJECTIF : Évaluer le rapport coût:efficacité de six approches thérapeutiques aux symptômes gastro-intestinaux hauts non investigués, dans le contexte canadien.

MÉTHODE : La présente étude a analysé les données de quatre essais randomisés visant à évaluer des populations homogènes et complémentaires de patients canadiens présentant des symptômes gastro-intestinaux hauts non investigués et des pronostics comparables. Le nombre de mois sans symptômes, les années de vie ajustées par la qualité (AVAQ) et les coûts directs en dollars canadiens de deux approches thérapeutiques établies à partir de l'outil de prise en charge clinique CanDys (pour Canadian Dyspepsia Working Group) et de quatre autres stratégies (deux agents antisécréteurs empiriques et deux endoscopies promptes) ont été analysés et comparés. Les auteurs ont inclus dans un modèle de Markov les données de prévalence, les probabilités, l'utilisation des services et les coûts, tandis que l'analyse de sensibilité a reposé sur des simulations de Monte Carlo. Les rapports coût:efficacité incrémentiels et les courbes d'acceptabilité coût:efficacité ont ainsi été déterminés.

RÉSULTATS : L'oméprazole en traitement empirique coûte 226 \$ par AVAQ (49 \$ par mois sans symptômes) par patient. L'oméprazole et les approches endoscopiques selon l'indice CanDys ont été plus efficaces mais plus coûteux que l'oméprazole en traitement empirique. Les options à base d'anti-H2 ont été moins efficaces que les approches par inhibiteurs de la pompe à protons (IPP). Aucune différence significative n'a été observée pour les rapports coût:efficacité incrémentiels. À mesure que les seuils de volonté de payer (VDP) croissaient de 226 \$à 24000 \$ par AVAQ, les approches antisécrétrices empiriques étaient moins susceptibles d'être le choix le plus économique, l'oméprazole selon l'indice CanDys devenant progressivement une option plus probable. Pour les valeurs de VDP allant de 24000 \$à 70000 \$ par AVAQ, l'éventail le plus cliniquement pertinent, l'oméprazole selon l'indice CanDys a été la stratégie la plus rentable (dans $32 \%$ à $46 \%$ des cas), la stratégie endoscopie prompte-IPP étant préférée avec les valeurs de VDP plus élevées.

CONCLUSIONS : Bien qu'aucune stratégie ne se soit démarquée comme la plus rentable, l'oméprazole selon l'indice CanDys pourrait être la stratégie de choix pour un éventail cliniquement pertinent d'hypothèses de VDP dans la prise en charge initiale des patients canadiens souffrant de dyspepsie non investiguée.

${ }^{1}$ Division of Gastroenterology; ${ }^{2}$ Division of Clinical Epidemiology, McGill University, Montréal, Quebec; ${ }^{3}$ Cliniques Universitaires St-Luc, Catholic University of Louvain, Brussels, Belgium; ${ }^{4}$ Faculty of Pharmacy, Université de Montréal, Montréal, Quebec; ${ }^{5}$ Division of Gastroenterology, McMaster University, Hamilton; ${ }^{6}$ Surrey GI Research Inc, Guelph, Ontario; ${ }^{7}$ University of Alberta, Edmonton, Alberta;

${ }^{8}$ Dalhousie University, Halifax, Nova Scotia; ${ }^{9}$ INSINConsulting, Guelph; ${ }^{10}$ AstraZeneca Canada Inc, Mississauga, Ontario

Correspondence: Dr Alan N Barkun, Department of Gastroenterology, Montreal General Hospital D7.148, Montreal, Quebec H3G 1A4.

Telephone 514-934-8309, fax 514-934-8531, e-mail alan.barkun@muhc.mcgill.ca

Received for publication October 21, 2009. December 22, 2009 
$U_{\text {si }}^{\text {n }}$ ninvestigated upper gastrointestinal (GI) symptoms often referred to as dyspepsia - have a worldwide prevalence estimated to be $28 \%$ to $40 \%(1,2)$. Dyspepsia accounts for a significant portion of physician consultations, with an average of 7\% of a Canadian family physician's practice devoted to its management (3). Similarly, in a survey conducted in the United States (4), dyspeptic patients were shown to be heavy users of health care resources, averaging 14 visits and US $\$ 3,850$ in overall health care charges per patient per year. The economic burden attributable to dyspepsia in the United Kingdom has been estimated to be approximately $£ 1$ billion per year (5).

There are a wide variety of treatment options for dyspepsia that have generated many clinical trials exploring the relative clinical efficacy and economic impact of various treatment strategies (6-15). A review (16) of economic evaluations of treatment strategies for functional (not uninvestigated) dyspepsia identified 18 such studies. However, because of the diversity of treatment options, this review was unable to identify the most cost-effective treatment strategy. A recently published randomized trial (17) assessed uninvestigated dyspepsia treatment; however, the United Kingdom setting may limit the generalizability of its conclusions to the Canadian setting.

The limitations in the existing literature make it difficult to identify the most efficient treatment approach for patients with dyspepsia. In 2000, the Canadian Dyspepsia Working Group (CanDys) developed an evidence-based approach (which was recently updated [18]) to the management of patients with uninvestigated upper GI symptoms using a broad definition of dyspepsia relevant to primary care practice, which included symptoms of heartburn and acid regurgitation in addition to dyspeptic symptoms of epigastric pain and discomfort identified by the Rome II definition $(19,20)$. The CanDys definition of dyspepsia, which includes patients with predominantly gastroesophageal reflux disease (GERD) symptoms, is consistent with guidelines from the National Institute for Clinical Excellence (21), endorsed by the British Society of Gastroenterology. The objective of the current economic evaluation was to compare the costs and outcomes over a 12-month period of two CanDys and four other initial treatment strategies for the management of Canadian patients with such upper GI symptoms. The evaluation used data from the Canadian Adult Dyspepsia Empiric Therapy (CADET) series of studies. These provided comparable outcome measures in similar patient groups investigated over a similar time horizon, thus providing a unique modelling opportunity with enhanced validity.

\section{Patient population}

\section{METHODS}

Data for the model were derived from four complementary CADET studies: CADET-H pylori Negative (CADET-HN) (22), CADET-Heartburn (CADET-HR) (23), CADET-H pylori positive (CADET-Hp) (24) and CADET-Prompt Endoscopy (CADET-PE) (25). The characteristics of the study populations provided a reasonably homogeneous overall study population for the model. Patients for all studies were selected using the same standardized CanDys definition of uninvestigated dyspepsia and included the upper GI symptoms described below; outcomes were assessed using similar symptom and health resource use measurement tools.
The study populations included adults presenting to their primary care physician with a three-month or longer duration of uninvestigated upper GI symptoms including the following: epigastric pain or discomfort, heartburn, acid regurgitation, excessive burping/belching, increased abdominal bloating, nausea, feeling of abnormal or slow digestion, or early satiety. These are all included in the CanDys definition of dyspepsia a definition adapted to the previously uninvestigated patient seen in the primary care setting $(18,26)$ - and represent its working definition in the model. In the treatment trials, patients were excluded if they presented with alarm symptoms (eg, unintentional weight loss, vomiting, dysphagia, hematemesis, melena, fever, jaundice or anemia) or were regular users of nonsteroidal anti-inflammatory drugs.

\section{Treatment strategies/management approaches}

A Markov model was used to compare the costs and effects of six strategies over 12 months for the initial treatment of adult patients with uninvestigated upper GI symptoms. Subsequent management approaches, which varied according to patient symptoms, are described below (see probabilities and symptom state data). The very rare state of gastric cancer among patients presenting with uninvestigated dyspepsia, at least in western societies, was not modelled for. No selected subjects from the original clinical trials were diagnosed with cancer and none died during the study period. The treatment strategies were as follows:

1. CanDys omeprazole: The CanDys Clinical Management

Tool (17) recommended stratifying patients into two groups of individuals presenting with dyspepsia: those in whom heartburn or reflux symptoms predominated, and those in whom dyspepsia heartburn or reflux symptoms did not predominate. Patients with heartburn-predominant symptoms were treated initially with omeprazole $20 \mathrm{mg}$ once daily for eight weeks. Patients with nonheartburnpredominant symptoms were tested for the presence of Helicobacter pylori infection using a urea breath test (UBT) (ie, test-and-treat approach). If results of the UBT were negative, patients were treated with omeprazole $20 \mathrm{mg}$ once daily for four weeks; if the UBT was positive, they were treated with one week of eradication triple therapy (omeprazole $20 \mathrm{mg}$ twice daily, metronidazole $500 \mathrm{mg}$ twice daily and clarithromycin $250 \mathrm{mg}$ twice daily).

2. CanDys ranitidine: This strategy was similar to the above strategy, with the $\mathrm{H}_{2}$-receptor antagonist $\left(\mathrm{H}_{2} \mathrm{RA}\right)$ ranitidine $150 \mathrm{mg}$ twice daily being substituted for omeprazole as antisecretory therapy, except for a step-up strategy to omeprazole for patients with heartburnpredominant symptoms despite four to eight weeks of ranitidine. The $H$ pylori eradication triple therapy for infected patients with nonheartburn-predominant symptoms remained the same.

3. Empirical omeprazole: Empirical omeprazole $20 \mathrm{mg}$ once daily for four to eight weeks (eight weeks for patients with heartburn-predominant symptoms) in all patients.

4. Empirical ranitidine: Empirical ranitidine $150 \mathrm{mg}$ twice daily for four to eight weeks (eight weeks for patients with heartburn-predominant symptoms) in all patients.

5. Endoscopy plus proton pump inhibitor (PPI): Prompt endoscopy was performed to determine the underlying disorder. Patients negative for $\mathrm{H}$ pylori and an endoscopic 
examination yielding no clinically significant lesion), or esophagitis or an ulcer treated initially with any PPI as well as those with such conditions who were $H$ pylori positive and treated initially with eradication triple therapy were selected for the model.

6. Endoscopy plus $\mathrm{H}_{2} \mathrm{RA}$ : This strategy was similar to the above strategy; however, subjects were chosen if an $H$ pylori-negative condition was treated initially with any $\mathrm{H}_{2} \mathrm{RA}$, and an $\mathrm{H}$ pylori-positive condition was treated initially with eradication triple therapy.

\section{Probabilities and symptom state data}

The two clinical end points for the measure of effectiveness adopted for the model were symptom-free months (SFMs) and quality-adjusted life-years (QALYs).

The probabilities and symptom data for the model were derived from patient-specific symptom state data from the four CADET trials. For the CanDys approaches (strategies 1 and 2), data were drawn from the randomized trials CADET-HN (22), CADET-HR (23) and CADET-Hp (24). For the prompt endoscopy approaches (strategies 5 and 6), data were drawn from the pragmatic (ie, observational) CADET-PE study (25). For the empirical antisecretory treatment approaches (strategies 3 and 4), data were derived from a constituted subsample of patients from the experimental or control groups described in the CADET-HN, -HR and -Hp studies. These studies did not contain a group of $H$ pylori-positive patients taking an initial four-week course of antisecretory therapy, and comparable outcomes and resource use data were not found in the literature. Therefore, the effect for this group was assumed by consensus of the expert clinician investigators (DA, AB, NC, CF, ABRT and SVZ) to be the same as for patients in the noneradication therapy arm of the CADET-Hp trial (treatment with omeprazole only once per day for seven days). Proportions of patients reporting heartburn-predominant symptoms and rates of $\mathrm{H}$ pylori infection in patients presenting with uninvestigated upper GI symptoms were based on those observed in subjects from the CADET-PE study (25) meeting the inclusion/exclusion criteria.

To calculate the effectiveness value of SFMs for the model, patient-derived symptom-free status was obtained from the trials. These were obtained according to responses of no/minor discomfort to questions about heartburn and reflux symptoms from the GI symptom rating scale (27) for patients with heartburnpredominant symptoms, and no/minimal problem responses on the validated seven-point Global Overall Symptom score (28) for patients with nonheartburn-predominant symptoms.

Probabilities to be symptom-free were derived from the clinical trial data based on subject status on trial enrollment: heartburn symptom predominant, nonheartburn symptom predominant ( $H$ pylori positive) and nonheartburn symptom predominant ( $\mathrm{H}$ pylori negative), and initial antisecretory treatment. Probabilities were established separately for each of these five patient groups using a modified per protocol approach, analyzing all patients reporting symptom status at the relevant visit. For periods between visits shorter or longer than three months, three-month transition probabilities were estimated (29).

Briefly, the CADET-HR study (23) randomly assigned 390 patients with heartburn-predominant symptoms to four to eight weeks of omeprazole or ranitidine, with patients 'stepped-up' for a further eight weeks of increased therapy if they remained symptomatic. The CADET-Hp trial (24) collected data on 294 patients with $H$ pylori-positive uninvestigated upper GI symptoms randomly assigned to one week of omeprazole or eradication triple therapy. The CADET-HN study (22) randomly assigned $512 \mathrm{H}$ pylori-negative patients with uninvestigated upper GI symptoms to treatment with omeprazole, ranitidine, cisapride or placebo using acute and on-demand therapy. From the overall CADET-Hp and CADET-HN populations, only patients with nonheartburnpredominant symptoms and taking omeprazole or ranitidine to populate the model were selected. In the CADET-PE study (25), 1040 adult patients with uninvestigated upper GI symptoms underwent prompt endoscopy within seven to 10 days of study entry. Treatment was selected by the family practitioner after receipt of the endoscopy results. Individuals who were negative for alarm symptoms and nonsteroidal anti-inflammatory drug use, and who were $H$ pylori positive and received a triple therapy initially, or were $H$ pylori negative and received a PPI or an $\mathrm{H}_{2} \mathrm{RA}$ initially, were included in the model.

\section{QALYs}

The following utility weights for health states were incorporated in the model taken from the literature $(30,31)$ : symptomatic dyspepsia 0.91; nonsymptomatic dyspepsia 1.00; and outpatient endoscopy 0.5675 for one day. Hospitalization, an unusual event in this patient population, was not accounted for in the QALY analysis.

\section{Costs}

Prices are expressed in 2007 Canadian dollars, and most are based on 2007 costs from the province of Ontario with the exception of endoscopy costs (32) (Table 1). Data were analyzed from the perspective of a third-party payer. Resource use associated with each cycle-specific health state was based on extraction of patientreported data from the respective CADET trials (data on file with AstraZeneca Canada Inc, Mississauga, Ontario) plus the costs for initial therapies. Information gained from the patient questionnaire, which was common to all of the trials, detailed resource use within the month immediately preceding the relevant visit which, with the exception of the CADET-HN trial, were data from subjects seen monthly. The extracted data were tripled and extrapolated to represent three-month data. Patient-estimated cost outlay for prescription drugs was increased by the health consumer price index to approximate current cost. For all patients, an initial visit with a general practitioner was assumed, plus the relevant initial prescription medication costs. For patients in the CanDys trial arms found to have nonheartburn-predominant symptoms, the cost of a UBT was added. In the CADET-HR study, patients failing to respond to initial treatment could be stepped-up to higher doses or a different medication; therefore, the increased medication costs were attributed to the patient group in accordance with the proportion of patients to whom a more expensive therapy was given. In the CADET-PE study, additional costs included initial consultation with a gastroenterologist, endoscopy and testing for $\mathrm{H}$ pylori. Otherwise, no protocol-driven resource use was included. The total for all patients per treatment arm per cycle was summed for each patient group, and an average cost per patient per cycle was estimated for each transition. In all cases, a modified per protocol approach was used, analyzing all patients who completed the relevant cycle. 


\section{TABLE 1}

\section{Unit costs}

\begin{tabular}{|c|c|}
\hline Unit cost variable & Cost per unit, \$ \\
\hline $\begin{array}{l}\text { Omeprazole } 20 \mathrm{mg} \text { od } \times 28 \text { days ( } 28 \text { tablets of } \\
\text { omeprazole at } \$ 1.547 / \text { tablet) }\end{array}$ & $43.32^{*}$ \\
\hline $\begin{array}{l}\text { Ranitidine } 150 \mathrm{mg} \text { bid } \times 28 \text { days (56 tablets of } \\
\text { ranitidine at } \$ 0.550 / \text { tablet) }\end{array}$ & $30.80^{*}$ \\
\hline $\begin{array}{l}\text { Triple therapy bid } \times 7 \text { days ( } 14 \text { tablets of omeprazole } 20 \mathrm{mg} \\
\text { at } \$ 1.547 / \text { tablet and } 14 \text { tablets of metronidazole } 500 \mathrm{mg} \\
\text { at } \$ 1.017 / \text { tablet and } 14 \text { tablets of clarithromycin } 250 \mathrm{mg} \text { at } \\
\$ 1.955 / \text { tablet) }\end{array}$ & $63.27^{*}$ \\
\hline GP consultation (A005) & $56.10^{\dagger}$ \\
\hline GP follow-up visit (A004) & $30.70^{\dagger}$ \\
\hline Gastroenterologist, visit with consultation (A415) & $127.50^{\dagger}$ \\
\hline Gastroenterologist, repeat consultation (A416) & $75.35^{\dagger}$ \\
\hline Surgeon, special surgical consultation (A935) & $127.50^{\dagger}$ \\
\hline Surgeon, repeat visit (A036) & $46.30^{\dagger}$ \\
\hline Endoscopy & $334.20^{\ddagger}$ \\
\hline $\begin{array}{l}\text { Nursing visit ( } 1 \mathrm{~h} \text { average salary for a registered nurse } \\
\text { in Ontario in 2003) }\end{array}$ & $26.34^{\S}$ \\
\hline $\begin{array}{l}\text { Test for Helicobacter pylori during endoscopy (L628 } \\
\text { microbiology other swabs } 25 \text { LMS at \$0.517/LMS) }\end{array}$ & $12.925^{\dagger}$ \\
\hline Day in hospital for stomach problem & $956.97^{\pi}$ \\
\hline $\begin{array}{l}\text { Barium meal (X104 diagnostic radiology of esophagus, } \\
\text { stomach and duodenum) }\end{array}$ & $86.90^{\dagger}$ \\
\hline Urea breath test (G166 and G167 hydrogen breath test) & $17.20^{\dagger}$ \\
\hline Barium enema (X112 diagnostic radiology) & $73.90^{\dagger}$ \\
\hline Blood test (L393 13 LMS plus L700 15 LMS) & $14.48^{\dagger}$ \\
\hline Urine test (L633 20 LMS plus L700 15 LMS) & $18.10^{\dagger}$ \\
\hline Stool culture (L630 34 LMS plus L700 15 LMS) & $25.33^{\dagger}$ \\
\hline Physiotherapist visit & $24.40^{\star \star}$ \\
\hline Other type of visit & $56.10^{\dagger}$ \\
\hline
\end{tabular}

*Based on Intercontinental Medical Statistics average weighted prices for Ontario 2007; ${ }^{\dagger}$ Ontario physician fee schedule, 2007. Ontario Ministry of Health and Long-term Care, January 2007; ${ }^{\ddagger} \$ 242$ (Estimate of $\$ 222.72$ in Goeree et al [32], increased by a factor of 1.087 representing the increase in the consumer price index [health care] for 2006), plus professional fee of $\$ 92.10$ (Z527 Ontario physician fee schedule); ${ }^{\circledR}$ Data from reference 47; "Weighted average (weighted by number of cases reported) of per diem cost of case mix groups from 255 to 297 inclusive from Health Costing in Alberta 2006 Annual Report; this is cost for 2004/2005); ${ }^{*}$ Ontario Health Insurance Plan insured physiotherapy services effective April 1, 2005 (V822) initial home visit (Bulletin $3070 \mathrm{MOH}$ ). bid Twice daily; GP General practitioner; LMS Labour, material and supervision; od once daily

\section{Model structure}

A decision analysis incorporating a Markov model was constructed for each alternative strategy (Figure 1) using TreeAge Pro (TreeAge Software Inc, USA). Markov models compactly represent situations in which there is an ongoing risk of a patient moving from one state of health to another. Assumptions, based on patient-specific CADET trial data, were the probabilities per unit of time (cycle of three months) that a patient in a given state (symptomatic) will 'transition' to each possible state (symptomatic versus asymptomatic) with the attributable costs. Thus, the discrete probabilities of becoming asymptomatic for each patient group were attributed to the first three-month cycle. Probabilities of health states in the second three-month cycle were conditional on both the treatment group and the health state at the end of the first cycle. The second cycle was repeated three times to provide outcomes at 12 months (a total of four cycles). Symptom state transition was assumed to occur at mid-cycle. The validation of the model structure was performed by a team of Canadian content experts comprised of the CADET Steering Committee (DA, NC, ABRT, SVZ, AB) and another expert clinician (CF), according to a previously used validation method (8).

\section{Sensitivity analysis}

A Monte Carlo simulation technique was performed. Monte Carlo methods are stochastic techniques, meaning that they are based on the use of random numbers and probability statistics to investigate problems. Using this methodology, the point estimates of assumptions adopted in the model were varied randomly according to the distributions derived from the CADET studies' data. Based on mean and SD, beta distributions were incorporated into the model to represent the probability to become symptom free, and gamma distributions were incorporated to represent the cost parameters for each subgroup cycle. The Monte Carlo simulation was run using all distributions - 5000 trials (each representing a fixed set of estimates) containing 5000 patients per sample. Tracker variables were used to ensure subjects retained their initial classifications throughout the simulations. Thus, the result was a range of cost and effect pairs of values for each strategy, which were presented as distributions. It is from these distributions that ranges and CIs of effect, cost, ratios of cost to effectiveness, and incremental cost, effect and cost-effectiveness ratios (ICERs) $(33,34)$ were derived. When comparing two strategies, the ICER is the ratio of incremental difference in cost to the incremental difference in effectiveness.

ICERs and their 95\% CIs were calculated and plotted for different pairs of strategies. The cost-effectiveness acceptability of the different strategies was estimated, using the incremental effectiveness, the incremental cost and the hypothetical willingness to pay (WTP) threshold of the decision maker(s) for an incremental unit of effectiveness. The resulting cost-effectiveness acceptability curves were plotted $(35,36)$, comparing all strategies. In such a display of the data, each line plot represents a strategy and its probability of cost-effectiveness according to increasing WTP thresholds given the data, such that the sum of probabilities (y axis) for every WTP threshold ( $\mathrm{x}$ axis, expressed in $\$$ per SFM) across all curves is 1.0 . The probability of 'being cost-effective' ( $y$-axis value) for a given value of WTP ( $x$-axis value) for each strategy corresponds to the proportion of all simulations in which each one of the strategies yielded a higher net health benefit than the competing alternatives (37). For descriptive purposes, a given y value will be referred to as the 'probability of being a cost-effective' choice.

\section{Probabilities}

\section{RESULTS}

The transition variables and 95\% CIs are listed in Table 2. Among patients with uninvestigated upper GI symptoms responding to the aforementioned inclusion/exclusion criteria, the probability of having heartburn-predominant symptoms was 39\%. The probability of having $H$ pylori infection was $30.1 \%$ overall, and $29 \%$ in those with nonheartburn-predominant symptoms.

\section{Costs}

The unit costs are shown in Table 1 . The detailed cost parameters derived for each subgroup for each cycle in the model are available on request. 


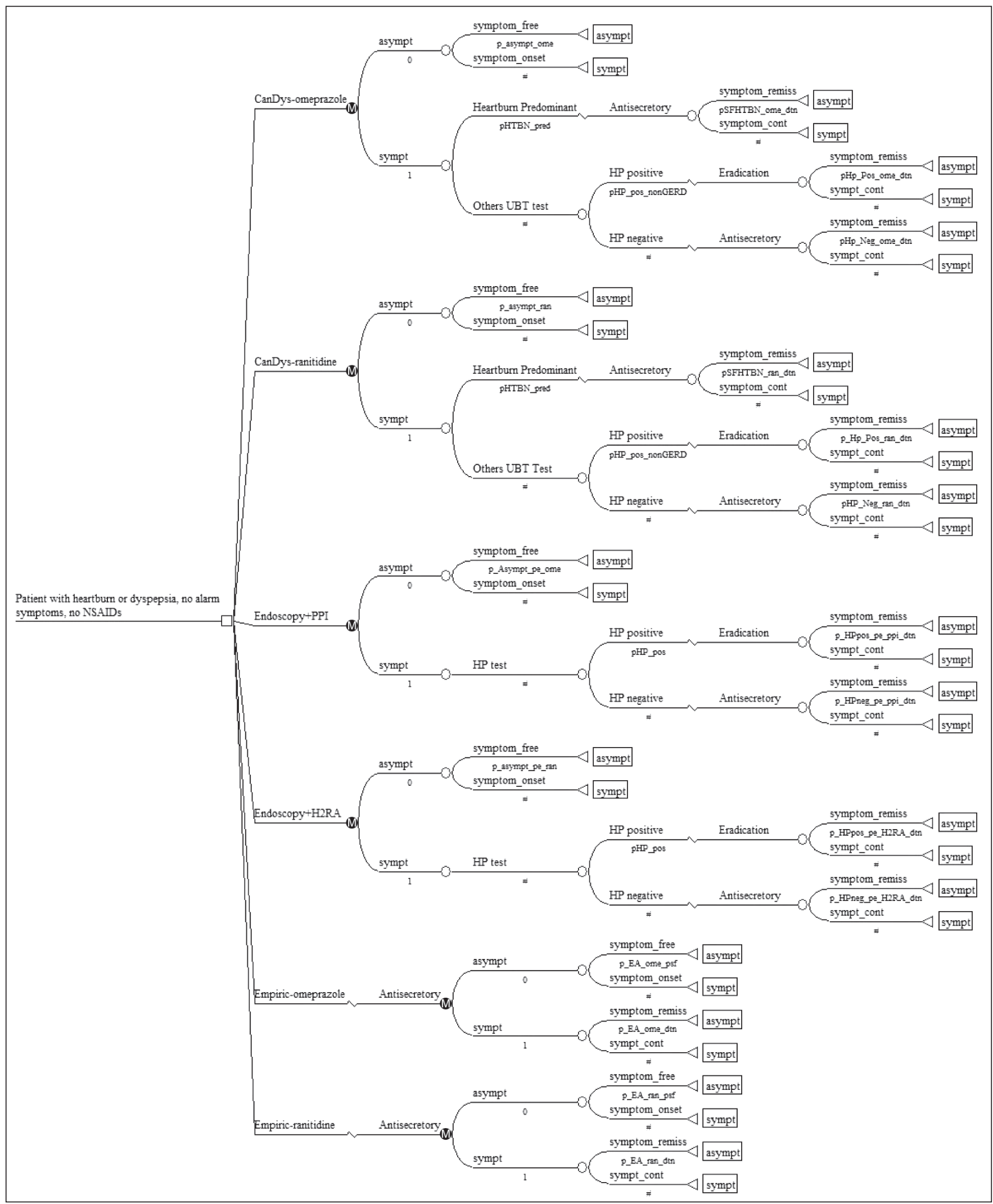

Figure 1) Markov model of 12-month treatment strategies for the management of uninvestigated dyspepsia. Open square: decision node; Solid circle (M): Markov node; Open circle: probability node; Triangle: terminal node. Each alternative is represented by a Markov model, and the stated probabilities determine the weight of each arm. The patient enters the model in the symptomatic state, and proceeds through the initial cycle, either ending in a symptomatic remission state or remaining symptomatic. In the Canadian Dyspepsia Working Group (CanDys) and prompt endoscopy alternatives, the symptom and Helicobacter pylori (Hp, HP) status probabilities are determined according to extracted trial data. Tracker variables were used to ensure that the appropriate probabilities and costs were associated with discrete patient groups and carried from one cycle to the next. Asympt Asymptomatic; cont Continue; EA Empirical antisecretory; GERD Gastroesophageal reflux disease; $\mathrm{H}_{2} \mathrm{RA} \mathrm{H}_{2}$-receptor antagonist; Hp neg Helicobacter pylori negative; NSAIDs Nonsteroidal anti-inflammatory drugs; ome omeprazole; pos Positive; PPI Proton pump inhibitor; pred Predominant; ran Ranitidine; remiss Remission; SFHTBN Free of heartburn symptoms; Sympt symptomatic; UBT Urea breath test 
TABLE 2

Transition probabilities

\begin{tabular}{|c|c|c|}
\hline & $\mathbf{n}$ & $\begin{array}{c}\text { Three-month } \\
\text { transition } \\
\text { probabilities* }\end{array}$ \\
\hline \multicolumn{3}{|c|}{ Patients symptom free at end of initial three-month cycle } \\
\hline Heartburn-predominant treated with omeprazole & 179 & $77.2(71-83)$ \\
\hline Heartburn-predominant treated with ranitidine & 173 & $72.5(66-79)$ \\
\hline $\begin{array}{l}\text { Nonheartburn-predominant Helicobacter pylori - } \\
\text { treated with omeprazole }\end{array}$ & 80 & $47.5(37-58)$ \\
\hline $\begin{array}{l}\text { Nonheartburn-predominant } H \text { pylori - treated with } \\
\text { ranitidine }\end{array}$ & 95 & $43.2(33-53)$ \\
\hline $\begin{array}{l}\text { Nonheartburn-predominant } H \text { pylori + treated with } \\
\text { OMC }\end{array}$ & 82 & $53.7(43-65)$ \\
\hline $\begin{array}{l}\text { Prompt endoscopy } H \text { pylori - treated with proton } \\
\text { pump inhibitor }\end{array}$ & 245 & $72.3(66-78)$ \\
\hline Prompt endoscopy $\mathrm{H}$ pylori - treated with $\mathrm{H}_{2} \mathrm{RA}$ & 152 & $68.7(61-76)$ \\
\hline Prompt endoscopy $H$ pylori + treated with OMC & 128 & $69.5(62-78)$ \\
\hline Empirical antisecretory treated with omeprazole & 345 & $57.3(52-63)$ \\
\hline Empirical antisecretory treated with ranitidine & 354 & $53.6(48-59)$ \\
\hline \multicolumn{3}{|c|}{$\begin{array}{l}\text { Patients symptom free at end of second three-month cycle if } \\
\text { symptom-free at end of initial cycle }\end{array}$} \\
\hline Heartburn-predominant treated with omeprazole & 146 & $9.7(5-15)$ \\
\hline Heartburn-predominant treated with ranitidine & 136 & $14.7(9-21)$ \\
\hline $\begin{array}{l}\text { Nonheartburn-predominant } H \text { pylori - treated with } \\
\text { omeprazole }\end{array}$ & 38 & $71.1(57-86)$ \\
\hline $\begin{array}{l}\text { Nonheartburn-predominant } H \text { pylori - treated with } \\
\text { ranitidine }\end{array}$ & 40 & $60.0(45-75)$ \\
\hline $\begin{array}{l}\text { Nonheartburn-predominant } H \text { pylori + treated with } \\
\text { OMC }\end{array}$ & 42 & $86.6(76-97)$ \\
\hline $\begin{array}{l}\text { Prompt endoscopy } \mathrm{H} \text { pylori - treated with proton } \\
\text { pump inhibitor }\end{array}$ & 108 & $70.7(62-79)$ \\
\hline Prompt endoscopy $\mathrm{H}$ pylori - treated with $\mathrm{H}_{2} \mathrm{RA}$ & 61 & $74.1(63-85)$ \\
\hline $\begin{array}{l}\text { Prompt endoscopy } \mathrm{H} \text { pylori + treated with triple } \\
\text { therapy }\end{array}$ & 54 & $88.6(80-97)$ \\
\hline Empirical antisecretory treated with omeprazole & 217 & $49.1(42-56)$ \\
\hline Empirical antisecretory treated with ranitidine & 209 & $46.1(39-53)$ \\
\hline \multicolumn{3}{|c|}{$\begin{array}{l}\text { Patients symptom free at end of second three-month cycle if } \\
\text { symptomatic at end of initial cycle }\end{array}$} \\
\hline Heartburn-predominant treated with omeprazole & 20 & $16.3(0-33)$ \\
\hline Heartburn-predominant treated with ranitidine & 25 & $10.6(0-23)$ \\
\hline $\begin{array}{l}\text { Nonheartburn-predominant } H \text { pylori - treated with } \\
\text { omeprazole }\end{array}$ & 40 & $22.5(10-35)$ \\
\hline $\begin{array}{l}\text { Nonheartburn-predominant } H \text { pylori - treated with } \\
\text { ranitidine }\end{array}$ & 50 & $24.0(12-36)$ \\
\hline $\begin{array}{l}\text { Nonheartburn-predominant } H \text { pylori + treated with } \\
\text { OMC }\end{array}$ & 38 & $36.7(21-52)$ \\
\hline $\begin{array}{l}\text { Prompt endoscopy } H \text { pylori - treated with proton } \\
\text { pump inhibitor }\end{array}$ & 71 & $22.0(12-32)$ \\
\hline Prompt endoscopy $\mathrm{H}$ pylori - treated with $\mathrm{H}_{2} \mathrm{RA}$ & 45 & $10.2(13-19)$ \\
\hline $\begin{array}{l}\text { Prompt endoscopy } H \text { pylori + treated with triple } \\
\text { therapy }\end{array}$ & 34 & $32.8(17-49)$ \\
\hline Empirical antisecretory treated with omeprazole & 98 & $23.8(15-32)$ \\
\hline Empirical antisecretory treated with ranitidine & 127 & $22.2(15-30)$ \\
\hline
\end{tabular}

*Transition probabilities are derived from clinical data probabilities using a two-stage conversion and presented as \% (95\% Cl). First, the probability for the relevant time period (three months) is estimated using the following fomula: $P=-t \times L N(1-r)$, where $t$ is the time factor and $r$ is the estimated rate of symptom-free subjects from the clinical trial. Second, the transitional probability is estimated using the following formula: Transitional probability $=-E X P(-P)$. $\mathrm{H}_{2} \mathrm{RA} \mathrm{H}_{2}$-receptor antagonist; OMC $\mathrm{H}$ pylori eradication triple therapy using omeprazole, metronidazole and clarithromycin, as described in the methods section; PPI Proton pump inhibitor
TABLE 3

Average and median costs and effectiveness, symptomfree months (SFMs) and quality-adjusted life-years (QALYs) for the six initial strategies

\begin{tabular}{|c|c|c|c|}
\hline \multirow[b]{2}{*}{ Strategy } & \multirow{2}{*}{$\begin{array}{c}\text { Average costs, \$ } \\
\text { Mean }(95 \% \mathrm{Cl}) \\
{[\text { median] }}\end{array}$} & \multicolumn{2}{|c|}{ Average effectiveness } \\
\hline & & $\begin{array}{l}\text { Mean SFMs } \\
(95 \% \mathrm{Cl})\end{array}$ & $\begin{array}{c}\text { Mean QALYs } \\
(95 \% \mathrm{Cl})\end{array}$ \\
\hline $\begin{array}{l}\text { CanDys } \\
\text { omeprazole }\end{array}$ & $\begin{array}{c}217(139-448) \\
{[195]}\end{array}$ & $\begin{array}{c}4.59 \\
(4.01-5.20)\end{array}$ & $\begin{array}{c}0.9444 \\
(0.9401-0.9490)\end{array}$ \\
\hline CanDys ranitidine & $\begin{array}{c}252(128-635) \\
{[207]}\end{array}$ & $\begin{array}{c}4.25 \\
(3.70-4.83)\end{array}$ & $\begin{array}{c}0.9419 \\
(0.9378-0.9462)\end{array}$ \\
\hline Empirical ranitidine & $\begin{array}{c}255(59-1,276) \\
{[155]}\end{array}$ & $\begin{array}{c}4.01 \\
(3.52-4.50)\end{array}$ & $\begin{array}{c}0.9401 \\
(0.9364-0.9438)\end{array}$ \\
\hline $\begin{array}{l}\text { Empirical } \\
\text { omeprazole }\end{array}$ & $\begin{array}{c}213(73-777) \\
{[154]}\end{array}$ & $\begin{array}{c}4.33 \\
(3.82-4.86)\end{array}$ & $\begin{array}{c}0.9425 \\
(0.9386-0.9465)\end{array}$ \\
\hline Endoscopy $+\mathrm{H}_{2} \mathrm{RA}$ & $\begin{array}{c}1,225(756-2,108) \\
{[1,151]}\end{array}$ & $\begin{array}{c}6.25 \\
(5.55-6.96)\end{array}$ & $\begin{array}{c}0.9557 \\
(0.9505-0.9610)\end{array}$ \\
\hline Endoscopy + PPI & $\begin{array}{c}1,560(647-4,533) \\
{[1,234]}\end{array}$ & $\begin{array}{c}6.52 \\
(5.93-7.11)\end{array}$ & $\begin{array}{c}0.9577 \\
(0.9533-0.9621)\end{array}$ \\
\hline
\end{tabular}

Costs in 2007 Canadian dollars. The median in effectiveness measures were not included because these closely approached the mean in all cases. CanDys Canadian Dyspepsia Working Group; $\mathrm{H}_{2} R A \mathrm{H}_{2}$-receptor antagonist; PPI Proton pump inhibitor

TABLE 4

Average and median cost-effectiveness ratios of cost per symptom-free month (SFM) and cost per quality-adjusted life-year (QALY) for the six initial strategies

\begin{tabular}{lcc}
\hline \multirow{2}{*}{ Strategy } & \multicolumn{2}{c}{ Mean cost, \$ (95\% CI) [median] } \\
\cline { 2 - 3 } CanDys omeprazole & \multicolumn{1}{c}{ Per SFM } & Per QALY \\
CanDys ranitidine & $60(29-99)[43]$ & $230(147-473)[206]$ \\
Empirical ranitidine & $64(15-315)[39]$ & $267(136-675)[220]$ \\
Empirical omeprazole & $49(17-179)[36]$ & $226(76-1,357)[165]$ \\
Endoscopy $+\mathrm{H}_{2} \mathrm{RA}$ & $197(118-341)[185]$ & $1,282(792-2,209)[1,205]$ \\
Endoscopy $+\mathrm{PPI}$ & $240(100-691)[190]$ & $1,629(676-4,732)[1,289]$ \\
\hline
\end{tabular}

Costs presented in 2007 Canadian dollars. CanDys Canadian Dyspepsia Working Group; $\mathrm{H}_{2} \mathrm{RA} \mathrm{H}_{2}$-receptor antagonist; PPI Proton pump inhibitor

Cost effectiveness and cost utility

Tables 3 and 4 summarize the point estimates and 95\% CIs for costs, effectiveness and cost-effectiveness ratios of the six strategies. Using point estimates, the least costly of the alternative approaches was empirical omeprazole, with CanDys omeprazole being slightly more effective at a higher cost, followed by endoscopy $+\mathrm{H}_{2} \mathrm{RA}$ and endoscopy + PPI. Two approaches, empirical ranitidine and CanDys ranitidine, were considered dominated, being more costly and less effective than the CanDys omeprazole approach. However, the 95\% CIs were wide and most often overlapping. There were few significant differences in the mean cost-effectiveness ratios, with the exception of the two endoscopy approaches that were both significantly greater than the CanDys omeprazole approach.

Incremental cost-effectiveness

Table 5 summarizes the ICERs (point estimates and 95\% CIs) for selected pairs of strategies. Many of the $95 \%$ CIs encompass zero, however, the two endoscopy approaches could be considered to be significantly more costly by this measure than both empirical omeprazole and CanDys omeprazole.

ICERs of $10 \%$ of the simulated trials of five of the strategies compared with the reference strategy of empirical omeprazole were graphed on a scatter plot (Figure 2). Such an illustration 
TABLE 5

Incremental cost-effectiveness ratios for the six initial strategies (per patient per year)

\begin{tabular}{llcc}
\hline Strategy & Comparator & $\begin{array}{c}\text { Mean incremental cost, \$lincremental } \\
\text { symptom-free month (95\% Cl) [median] }\end{array}$ & $\begin{array}{c}\text { Mean incremental cost, \$lincremental } \\
\text { quality-adjusted life-year (95\% Cl) [median] }\end{array}$ \\
\hline CanDys ranitidine & Empirical omeprazole & $-908(-5,568$ to $+5,459)[-40]$ & $-121,104(-742,429$ to $+727,877)[-5,328]$ \\
CanDys omeprazole & Empirical omeprazole & $+197(-3,894$ to $+3,692)[+56]$ & $+26,321(-519,155$ to $+492,323)[+7,409]$ \\
Empirical ranitidine & Empirical omeprazole & $+438(-5,599$ to $+5,273)[-6]$ & $+58,448(-746,485$ to $+703,044)[-860]$ \\
Endoscopy $+\mathrm{H}_{2} \mathrm{RA}$ & Empirical omeprazole & $+559(+145$ to $+1,228)[+517]$ & $+82,497(+20,709$ to $+190,546)[+75,332]$ \\
Endoscopy $+\mathrm{PPI}$ & Empirical omeprazole & $+640(+126$ to $+2,107)[+492]$ & $+92,690(+18,133$ to $+306,405)[+70,999]$ \\
Endoscopy $+\mathrm{PPI}$ & CanDys omeprazole & $+740(+192$ to $+2,417)[+545]$ & $+109,163(+27,607$ to $+355,615)[+79,581]$ \\
Endoscopy $+\mathrm{H}_{2} \mathrm{RA}$ & CanDys omeprazole & $+681(+261$ to $+1,557)[+584]$ & $+108,415(+37,555$ to $+253,817)[+86,358]$ \\
Endoscopy $+\mathrm{PPI}$ & Endoscopy $+\mathrm{H}_{2} \mathrm{RA}$ & $+2,795(-16,875$ to $+19,049)[+83]$ & $+372,704(-2.25 \mathrm{M}$ to $+2.54 \mathrm{M})[+11,008]$ \\
\hline
\end{tabular}

Simulated trials showing zero incremental differences were excluded. CanDys Canadian Dyspepsia Working Group; $\mathrm{H}_{2} \mathrm{RA} \mathrm{H}_{2}$-receptor anagonist; $\mathrm{M}$ Million; PPI Proton pump inhibitor

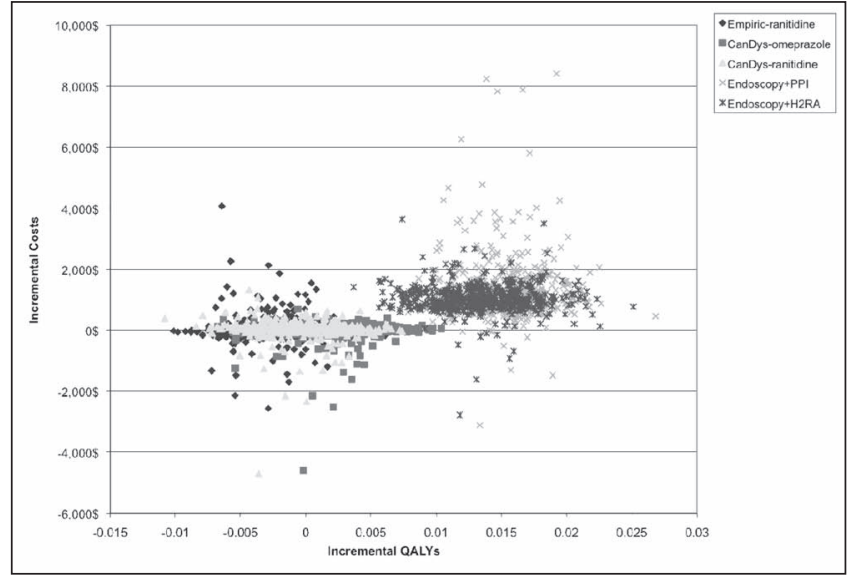

Figure 2) Incremental cost-effectiveness defined as incremental costs $(\$) /$ incremental quality-adjusted life-year (QALY) compared with the baseline (least costly) strategy: Empirical omeprazole (each mark represents a simulation). Note that the y axis was truncated at $\$ 10,000$ to better illustrate the results and a sample of 500 simulations was charted. CanDys Canadian Dyspepsia Working Group; $\mathrm{H}_{2} \mathrm{RA} \mathrm{H}_{2}$-receptor antagonist; PPI Proton pump inhibitor

of the ICERs of the simulations enable us to see the variability of the pair-wise comparisons. For example, the following observations related to the CanDys omeprazole strategy can be made:

- It is less effective than empirical omeprazole in

1285 simulations (25.7\%);

-It dominates empirical omeprazole in 1154 simulations

(23\%), being more effective and less costly;

- It is dominated by empirical omeprazole in only

882 simulations (18\%), being less effective and more costly;

-It is more effective than empirical omeprazole, but at a

higher cost in $38 \%$ of the simulations; and

- It is less effective than empirical omeprazole at a lower cost in $4 \%$ of the simulations.

Cost acceptability curves for QALYs are shown in Figure 3. WTP values of less than $\$ 226$ per QALY would correspond to a negative net health benefit for all strategies. For WTP values of \$226 per QALY or greater, the empirical omeprazole approach remains the cost-effective choice until approximately $\$ 24,000$ per QALY, when it is superseded by CanDys omeprazole. For WTP ranging from $\$ 24,000$ to $\$ 70,000$ per

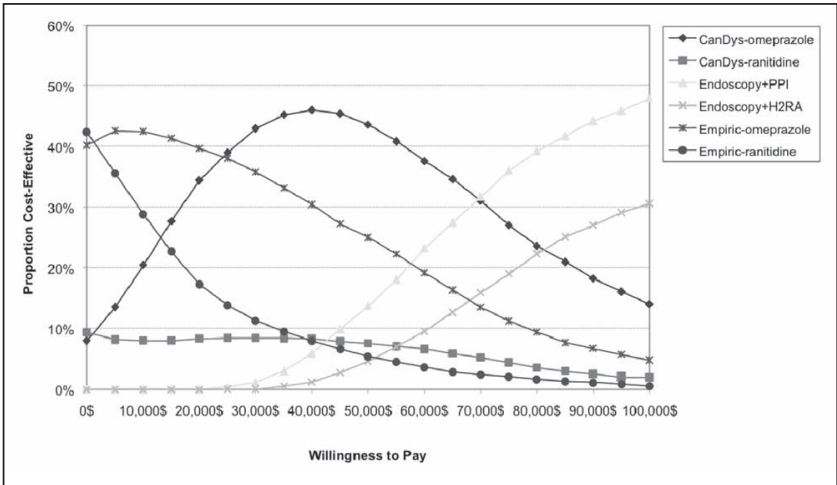

Figure 3) Acceptability curve of all strategies. Plot representing the changing percentage of iterations for which each comparator is cost effective relative to all other strategies. The $x$ axis displays varying levels of willingness to pay (\$per quality-adjusted life-year) and the $y$ axis displays the proportion of simulations falling under this threshold. Note that the $x$ axis has been truncated at $\$ 100,000$ to better illustrate the changing curves. CanDys Canadian Dyspepsia Working Group; $\mathrm{H}_{2} \mathrm{RA} \mathrm{H}_{2}$-receptor antagonist; PPI Proton pump inhibitor

QALY, CanDys omeprazole is the most likely cost-effective strategy. Endoscopy + PPI was the most likely strategy to be selected for WTP values of more than $\$ 70,000$ per QALY. Throughout the illustrated range of WTP thresholds, no single strategy exhibited a probability of more than 0.50 for being the most cost-effective choice; however, endoscopy + PPI exhibited a probability of nearly $67 \%$ of being the most cost-effective choice at a WTP of $\$ 400,000$.

\section{DISCUSSION AND CONCLUSIONS}

Despite extensive research into this common condition, the optimal cost-effective strategy for the initial primary care management of patients with uninvestigated upper GI symptoms remains uncertain. A Cochrane systematic review (14) of 25 trials reporting 27 comparisons concluded that a strategy of PPI therapy was significantly more effective than either $\mathrm{H}_{2} \mathrm{RAs}$ or antacids; more recently, a step-up approach has been shown to be more cost effective than a step-down approach at six months (38). A strategy of 'test and treat' for H pylori infection may also be more effective than acid suppression alone (14), perhaps in part because the knowledge of $H$ pylori absence may decrease subsequent resource use (39). 
A recent cluster randomized trial (40) compared empirical PPI therapy with testing for $\mathrm{H}$ pylori, or a combination of the two. The strategies based on H pylori testing led to similar symptom resolution, but reduced endoscopic workload and lowered one-year total costs compared with empirical antisecretory therapy. Most recently, a meta-analysis (41) that included the large Medical Research Council-Carbon-13 Urea Breath Test and Eradication (MRC-CUBE) randomized controlled trial (RCT) (17) of 699 patients suggested that both test and treat, and empirical PPI use were equally cost effective in patients with dyspepsia in a primary care setting, and that the choice should, thus, be driven by patient and physician preference.

In a meta-analysis by Delaney et al (14), initial endoscopy was associated with a small reduction in the risk of recurrent dyspeptic symptoms compared with the $H$ pylori test and treat strategy, but was not cost effective. An individual patient meta-analysis from the same group (15) suggested that prompt endoscopy conferred a small benefit in terms of the cure of dyspepsia, but cost more than 'test and treat', and was not a cost-effective strategy for the initial management of dyspepsia (prompt endoscopy eventually became cost effective only when the WTP per patient symptom-free of dyspepsia reached $\$ 180,000)$. Two recent RCTs $(42,43)$ completed in Asia suggested that a test-and-treat approach may be more cost effective than prompt endoscopy but results in less satisfaction (42), while the test-and-treat approach is as effective but more cost effective than prokinetic administration or prompt endoscopy (43).

All of the aforementioned data suffer from heterogeneity in trial designs or patient populations, and do not provide a global comparison across the existing wide variety of treatment options in a comparable setting, let alone one that is most adapted to Canadian practice.

Because no RCT has been large enough to compare all viable initial strategies in patients with uninvestigated upper GI symptoms, investigators have also turned to decision models. However, here too (even though accepting and quantifying uncertainty is an aim of cost-effectiveness analyses), many factors may limit analytical conclusions such as the following: disparate modelling methodologies, variations in study parameters such as study design, strategies (some now outdated), patient populations, base case assumptions, measurements of outcome and time horizons. This is especially true because decision models generally also incorporate data from disparate trials, and are highly influenced by parameters such as endoscopy costs, treatment and physician visits, the prevalence of $H$ pylori, the specificity of diagnostic tests, as well as the short- and longterm benefits of $H$ pylori eradication in patients with functional nonulcer dyspepsia (44).

The CADET program, comprised of one observational and three randomized trials, was specifically designed to provide a large body of homogeneous data on the prevalence and initial management of uninvestigated upper GI symptoms, and currently exists as the most comprehensive sole data source available in uninvestigated dyspepsia, designed to be linked for an analysis such as the current one. As a result - and most importantly - the trials had comparable study populations, comparable validated symptom and health resource outcome measures, comparable follow-up durations, and were all completed within the same four-year time span. Decision modelling using these data, thus, provides a particularly meaningful, homogeneous health economic analysis from the increased statistical power of the pooled study arms. This enables a global quantification of all six initial management strategies. The probabilities included in the model are all taken directly from CADET studies (22-25). The sensitivity analysis performed enabled us to assess wide variations of point estimates of probabilities and costs, including $\mathrm{H}$ pylori prevalence, and the cost of omeprazole (as part of an overall direct cost attributable to each strategy).

The CADET studies used the terminology 'uninvestigated dyspepsia' to refer to all patients with uninvestigated upper GI symptoms including both heartburn-predominant and nonheartburn-predominant symptoms, consistent with the CanDys recommendations (18). Indeed, the CanDys terminology is a broader definition of dyspepsia than perhaps used or accepted in other areas of the world, but it was considered to be more in keeping with the conceptual framework adopted by primary care physicians for patients presenting with uninvestigated upper GI symptoms as discussed elsewhere $(18,21,26)$. Nonetheless, all included CADET study patients did have epigastric pain or discomfort; in contradistinction, those with sole heartburn and/or acid regurgitation were considered to have GERD - not dyspepsia - and were not enrolled in the CADET program.

Point estimates suggested that both the empirical ranitidine strategy and the CanDys ranitidine strategy are dominated (less effective and more costly than CanDys omeprazole). The empirical ranitidine strategy is the least effective and the empirical omeprazole strategy is the least costly. The endoscopy strategies are more effective, but at higher incremental costs. In all cases, the ranitidine alternatives were less effective than their corresponding omeprazole/PPI strategies. The CanDys ranitidine strategy in the current model was based on the CADET-HR study in which almost one-half of the patients were stepped-up to omeprazole. This favoured the ranitidine strategies because the patients who stepped-up to omeprazole were considered to be ranitidine responders in the model (intention-to-treat data analysis), thus, artificially increasing the efficacy of a ranitidine-based first strategy.

Unfortunately, despite the large numbers of patients pooled for the present economic analysis, the variability in costs did not allow us to draw a definite conclusion about the respective cost-effectiveness of each strategy when taking into account the usual 95\% CIs of the ICERs. Variability was increased by the higher resource use in the CADET-PE trial, which reflected the observational nature of that study.

The cost-acceptability curves provide a good summary of the main conclusions of the study. No strategy distinguished itself as the overwhelming choice across the full range of WTP values. The most clinically relevant WTP range may be the interval over which CanDys omeprazole was the strategy of choice. Indeed, in an attempt to anchor such considerations, the results by Kleinman et al (45) are useful and suggest that GERD sufferers were willing to pay up to $\$ 182$ to obtain complete relief in a short period of time without side effects. In the overall interpretation of the results, one should also consider the feasibility of prompt endoscopy in all patients with uninvestigated dyspepsia in the era of screening colonoscopy, with already limited equipment and human endoscopic resources (46). 
There are several limitations to the model. Costs and outcomes were modelled over one year; however, dyspepsia is often a recurrent condition, which may last for many years and eventually require endoscopy. Thus, the model may overestimate the benefits of the CanDys omeprazole strategy over those of prompt endoscopy. Because all data were derived from the CADET studies, the results are specifically applicable to the Canadian health care system. Factors in other health care systems that may limit generalizability of the results to other countries would include the following: the greater availability of direct or open-access endoscopy, eliminating the cost of a gastroenterological consultation; variability of endoscopy costs and possible differing proportionality of the cost-structure; and the availability of over-the-counter PPIs, which would eliminate pharmacy dispensing fees. Although the results likely represent class effects, there are no such homogeneous, summary, high-quality data using $\mathrm{H}_{2} \mathrm{RAs}$ or PPIs other than omeprazole and ranitidine.

We have attempted to better characterize the cost-effectiveness of competing initial strategies in the management of patients with uninvestigated upper GI symptoms in the primary care setting using coherent data drawn from the CADET studies. There are marked overlaps in the CIs of the ICER assessments. Based on the model assumptions, the WTP analysis suggests that no single strategy is most likely to be cost effective over a wide range of WTP thresholds; yet, the CanDys omeprazole approach may be the most likely to be cost effective, assuming clinically relevant WTP estimates in the management of patients with uninvestigated upper GI symptoms over the year following the initial patient-physician encounter. Endoscopic approaches may be marginally more effective, but the increased incremental costs are high.

\section{REFERENCES}

1. Haycox A, Einarson T, Eggleston A. The health economic impact of upper gastrointestinal symptoms in the general population: Results from the Domestic/International Gastroenterology Surveillance Study (DIGEST). Scand J Gastroenterol Suppl 1999;231:38-47.

2. Penston JG, Pounder RE. A survey of dyspepsia in Great Britain. Aliment Pharmacol Ther 1996;10:83-9.

3. Chiba N, Bernard L, O Brien BJ, Goeree R, Hunt RH. A Canadian physician survey of dyspepsia management. Can J Gastroenterol 1998;12:83-90.

4. Rabeneck L, Menke T. Increased numbers of women, older individuals, and Blacks receive health care for dyspepsia in the United States. J Clin Gastroenterol 2001;32:307-9.

5. Moayyedi P, Mason J. Clinical and economic consequences of dyspepsia in the community. Gut 2002;50(Suppl 4):iv10-2.

6. Ebell MH, Warbasse L, Brenner C. Evaluation of the dyspeptic patient: A cost-utility study. J Fam Pract 1997;44:545-55.

7. Fendrick AM, Chernew ME, Hirth RA, Bloom BS. Alternative management strategies for patients with suspected peptic ulcer disease. Ann Intern Med 1995;123:260-8.

8. Makris N, Barkun A, Crott R, Fallone CA. Cost-effectiveness of alternative approaches in the management of dyspepsia. Int J Technol Assess Health Care 2003;19:446-64.

9. Moayyedi P, Soo S, Deeks J, et al. Systematic review and economic evaluation of Helicobacter pylori eradication treatment for non-ulcer dyspepsia. Dyspepsia Review Group. BMJ 2000;321:659-64.

10. Ofman JJ, Etchason J, Fullerton S, Kahn KL, Soll AH. Management strategies for Helicobacter pylori-seropositive patients with dyspepsia: Clinical and economic consequences. Ann Intern Med 1997;126:280-91.

11. Silverstein MD, Petterson T, Talley NJ. Initial endoscopy or empirical therapy with or without testing for Helicobacter pylori for dyspepsia: A decision analysis. Gastroenterology 1996;110:72-83.

12. Sonnenberg A. Cost-benefit analysis of testing for Helicobacter pylori in dyspeptic subjects. Am J Gastroenterol 1996;91:1773-7.
ACKNOWLEDGEMENTS: The authors thank Ms Viviane Adam, D Eduardo da Silveira, Ms Krystyna Stewart and Ms Myriam Martel for assisting in the review and preparation of the manuscript.

DISCLOSURES: Dr Barkun is a research scholar (Chercheur National) of the Fonds de la Recherche en Santé du Québec. Dr Kennedy was associated, during this work, with the Aventis chair in Medication Use, Social and Policy Implications at the Faculty of Pharmacy. Dr Veldhuyzen van Zanten is the recipient of a Nova Scotia Clinical Research Scholar Award.

POSSIBLE CONFLICTS OF INTEREST: Drs Armstrong, Barkun, Chiba, Fallone, Thomson, Veldhuyzen van Zanten, Lachaine, Kennedy and Mr Sinclair are consultants, have received research funding, and/or are or have been members of the speaking bureau for one or more of the following industrial partners in the past three years: Abbott Laboratories (SVZ, CF, DA, JL, NC), AstraZeneca Canada Inc (AB, DA, NC, CF, SVZ), Nycomed Inc (AB, CF, DA, NC), Axcan Pharma Inc (SVZ, DA, NC, CF), Janssen-Ortho (CF, DA, JL, NC), Merck Frost Canada (JL, WK), Aventis Pharma Inc (WK) and Novartis (CF, DA, JL). Mr Escobedo, Ms Kalra, Ms Nevin, Ms Smyth and Dr White are all employees of AstraZeneca Canada Inc. Mr Chakraborty is a former employee of AstraZeneca Canada Inc.

FUNDING: This work was funded, in part, by an unrestricted grant from AstraZeneca Canada Inc. The funding sponsor was involved in the conception of the project, and assisted in providing clinical data from the CADET studies. The sponsor did not contribute to the design of the model structure, nor did it perform any of the presented analyses, but did have an opportunity to review the manuscript.

13. Spiegel BM, Vakil NB, Ofman JJ. Dyspepsia management in primary care: A decision analysis of competing strategies. Gastroenterology 2002;122:1270-85.

14. Delaney B, Ford AC, Forman D, Moayyedi P, Qume M. Initial management strategies for dyspepsia. Cochrane Database Syst Rev 2005(4):CD001961.

15. Ford AC, Qume M, Moayyedi P, et al. Helicobacter pylori test and treat or endoscopy for managing dyspepsia: An individual patient data meta-analysis. Gastroenterology 2005;128:1838-44.

16. Garcia-Altes A, Jovell E. Economic analysis of treatment of functional dyspepsia. An assessment of the quality of published studies. Int J Technol Assess Health Care 2001;17:517-27.

17. Delaney BC, QumeM, Moayeddi P, et al. Helicobacter pylori test and treat versus proton pump inhibitor initial management of dyspepsia in primary care: Multicentre randomised controlled trial (MRC-CUBE trial). BMJ 2008;336:651-4.

18. Veldhuyzen van Zanten SJ, Bradette M, Chiba N, et al. Evidence-based recommendations for short- and long-term management of uninvestigated dyspepsia in primary care: An update of the Canadian Dyspepsia Working Group (CanDys) clinical management tool. Can J Gastroenterol 2005;19:285-303.

19. Talley N, Colin-Jones D, Koch K, Koch M, Nyren O, Stanghellini V. Functional dyspepsia: A classification with guidelines for diagnosis and management. Gastroenterology Int 1991;4:145-60.

20. Talley NJ, Stanghellini V, Heading RC, Koch KL, Malagelada JR, Tytgat GN. Functional gastroduodenal disorders. Gut 1999;45(Suppl 2):II37-42.

21. National Institute for Clinical Excellence. Dyspepsia: Managing dyspesia in adults in primary care, 2004. <http://www.nice.org.uk/ nicemedia/live/10950/29459/29459.pdf.> (Accessed July 14, 2010).

22. Veldhuyzen van Zanten SJ, Chiba N, Armstrong D, et al.

A randomized trial comparing omeprazole, ranitidine, cisapride, or placebo in helicobacter pylori negative, primary care patients with dyspepsia: The CADET-HN Study. Am J Gastroenterol 2005;100:1477-88. 
23. Armstrong D, Veldhuyzen van Zanten SJ, Barkun AN, et al. Heartburn-dominant, uninvestigated dyspepsia: A comparison of 'PPI-start' and 'H2-RA-start' management strategies in primary care the CADET-HR Study. Aliment Pharmacol Ther 2005;21:1189-202.

24. Chiba N, Veldhuyzen van Zanten S, Sinclair P, Ferguson RA, Escobedo S, Grace E. Treating Helicobacter pylori infection in primary care patients with uninvestigated dyspepsia: The Canadian Adult Dyspepsia Empiric Treatment-Helicobacter pylori positive (CADET-Hp) randomised controlled trial. BMJ 2002;324:1012-6.

25. Thomson AB, Barkun AN, Armstrong D, et al. The prevalence of clinically significant endoscopic findings in primary care patients with uninvestigated dyspepsia: The Canadian Adult Dyspepsia Empiric Treatment-Prompt Endoscopy (CADET-PE) study. Aliment Pharmacol Ther 2003;17:1481-91.

26. Chiba N. Treat the patients' main dyspepsia complaint, not the ROME criteria. Am J Gastroenterol 2004;99:1059-62.

27. Revicki DA, Wood M, Wiklund I, Crawley J. Reliability and validity of the Gastrointestinal Symptom Rating Scale in patients with gastroesophageal reflux disease. Qual Life Res 1998;7:75-83.

28. Veldhuyzen van Zanten SJ, Chiba N, Armstrong D, et al. Validation of a 7-point Global Overall Symptom scale to measure the severity of dyspepsia symptoms in clinical trials. Aliment Pharmacol Ther 2006;23:521-9.

29. Fleurence RL, Hollenbeak CS. Rates and probabilities in economic modeling transformation, translation and appropriate application. Pharmacoeconomics 2007;25:3-6.

30. Elliott RA, Hooper L, Payne K, et al. Preventing non-steroidal anti-inflammatory drug-induced gastrointestinal toxicity: Are older strategies more cost-effective in the general population? Rheumatology 2006;45:606-13.

31. Groeneveld PW, Lieu TA, Fendrick AM, et al. Quality of life measurement clarifies the cost-effectiveness of Helicobacter pylori eradication in peptic ulcer disease and univestigated dyspepsia. Am J Gastroenterol 2001;96:338-47.

32. Goeree R, O Brien B, Hunt R, Blackhouse G, Willan A, Watson J. Economic evaluation of long-term management strategies for erosive oesophagitis. Pharmacoeconomics 1999;16:679-97.

33. Briggs AH, Goeree R, Blackhouse G, O'Brien BJ. Probabilistic analysis of cost-effectiveness models: Choosing between treatment strategies for gastroesophageal reflux disease. Med Decis Making 2002;22:290-308.

34. van Hout BA, Al MJ, Gordon GS, Rutten FF. Costs, effects and C/E-ratios alongside a clinical trial. Health Econ 1994;3:309-19.

35. Briggs A. Handling uncertainty in economic evaluation and presenting the results. In: Drummond M, McGuire A, eds.
Economic Evaluation in Health Care: Merging Theory with Practice. New York: Oxford University Press, 2001:172-214.

36. Delaney BC, Wilson S, Roalfe A, et al. Cost effectiveness of initial endoscopy for dyspepsia in patients over age 50 years: A randomised controlled trial in primary care. Lancet 2000;356:1965-9.

37. Laska EM, Meisner M, Siegel C, Wanderling J. Statistical determination of cost-effectiveness frontier based on net health benefits. Health Econ 2002;11:249-64.

38. van Marrewijk CJ, Mujakovic S, Fransen GAJ, et al. Effect and cost-effectiveness of step-up versus step-down treatment with antacids, $\mathrm{H}_{2}$-receptor antagonists, and proton pump inhibitors in patients with new onset dyspepsia (DIAMOND study): A primarycare-based randomised controlled trial. Lancet 2009;373:215-25.

39. Ford AC, Dorman D, Nathan J, Crocombe WD, Axon AT, Moayyedi P. Clinical trial: Knowledge of negative Helicobacter pylori status reduces subsequent dyspepsia-related resource use. Aliment Pharmacol Ther 2007;26:1267-75.

40. Jarbol DE, Kragstrup J, Stovring $\mathrm{H}$, et al. Proton pump inhibitor or testing for Helicobacter pylori as the first step for patients presenting with dyspepsia? A cluster-randomized trial. Am J Gastroenterol 2006;101:1200-8.

41. Ford AC, Moayyedi P, Jarbol DE, et al. Meta-analysis: Helicobacter pylori 'test and treat' compared with empirical acid suppression for managing dyspepsia. Aliment Pharmacol Ther 2008;28:534-44.

42. Mahaveda S, Chia Y-C, Vinothini A, Mohzami M, Goh K-L. Cost-effectiveness and satisfaction with a Helicobacter pylori "test and treat" strategy compared with prompt endoscopy in young Asians with dyspepsia. Gut 2008;57;1214-20.

43. Wayne HC Hu, SK Lam, Cindy LK Lam, et al. Comparison between empirical prokinetics, Helicobacter test-and-treat and empirical endoscopy in primary-care patients presenting with dyspepsia: A one-year study. World J Gastroenterol 2006;12:5010-6.

44. Arents NL, Thijs JC, Kleibeuker JH. A rational approach to uninvestigated dyspepsia in primary care: Review of the literature. Postgrad Med J 2002;78:707-16.

45. Kleinman L, McIntosh E, Ryan M, et al. Willingness to pay for complete symptom relief of gastroesophageal reflux disease. Arch Intern Med 2002;162:1361-6.

46. Armstrong D, Barkun AN, Chen Y, et al. Access to specialist gastroenterology care in Canada: The Practice Audit in Gastroenterology (PAGE) Wait Times Program. Can J Gastroenterol 2008;22:155-60.

47. Pyper W. Employment trends in nursing. Perspectives on Labour and Income. Statistics Canada 2004;5:11:5-17. 


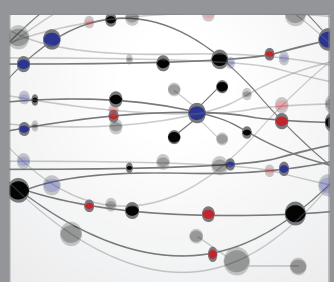

The Scientific World Journal
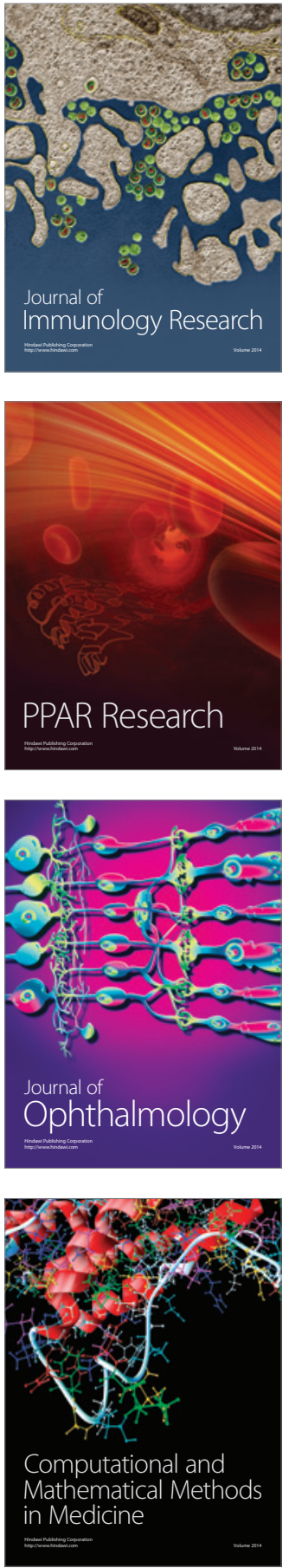

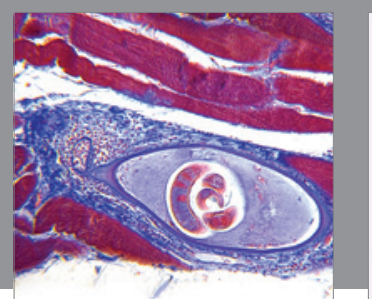

Gastroenterology Research and Practice

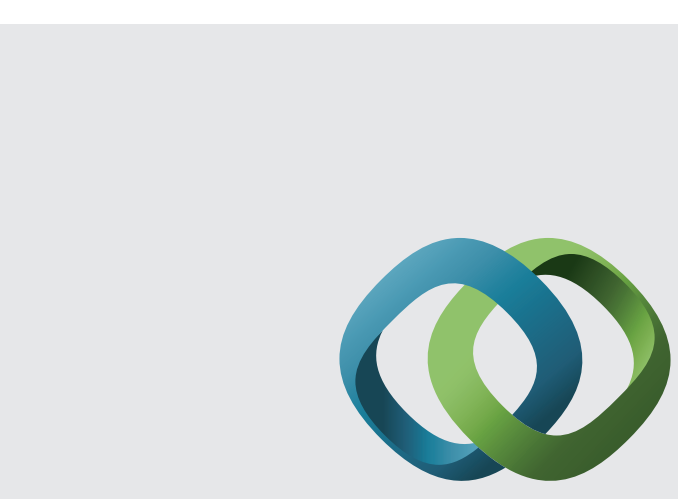

\section{Hindawi}

Submit your manuscripts at

http://www.hindawi.com
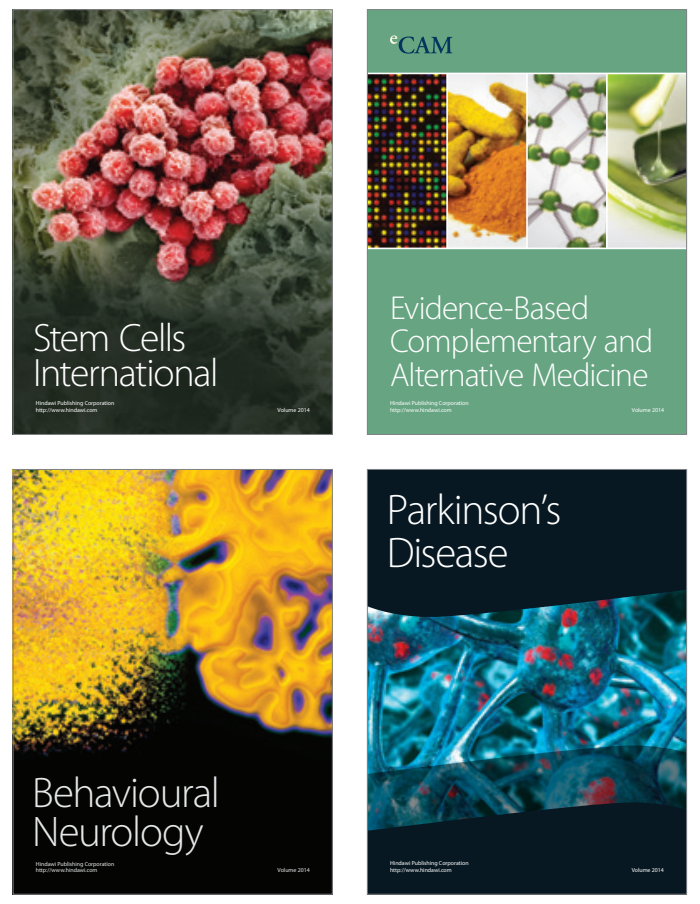
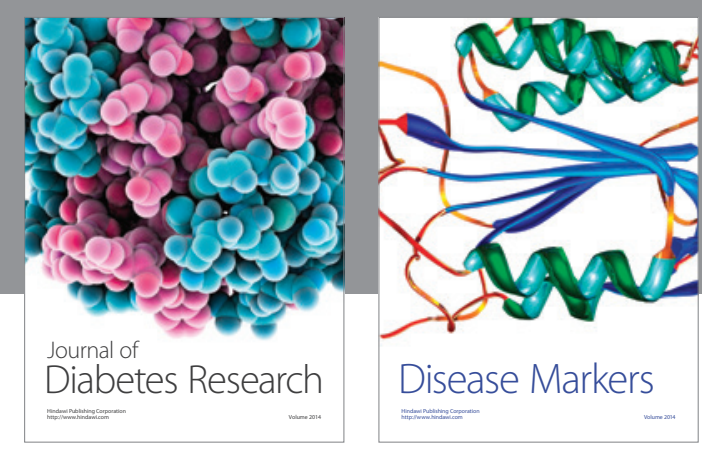

Disease Markers
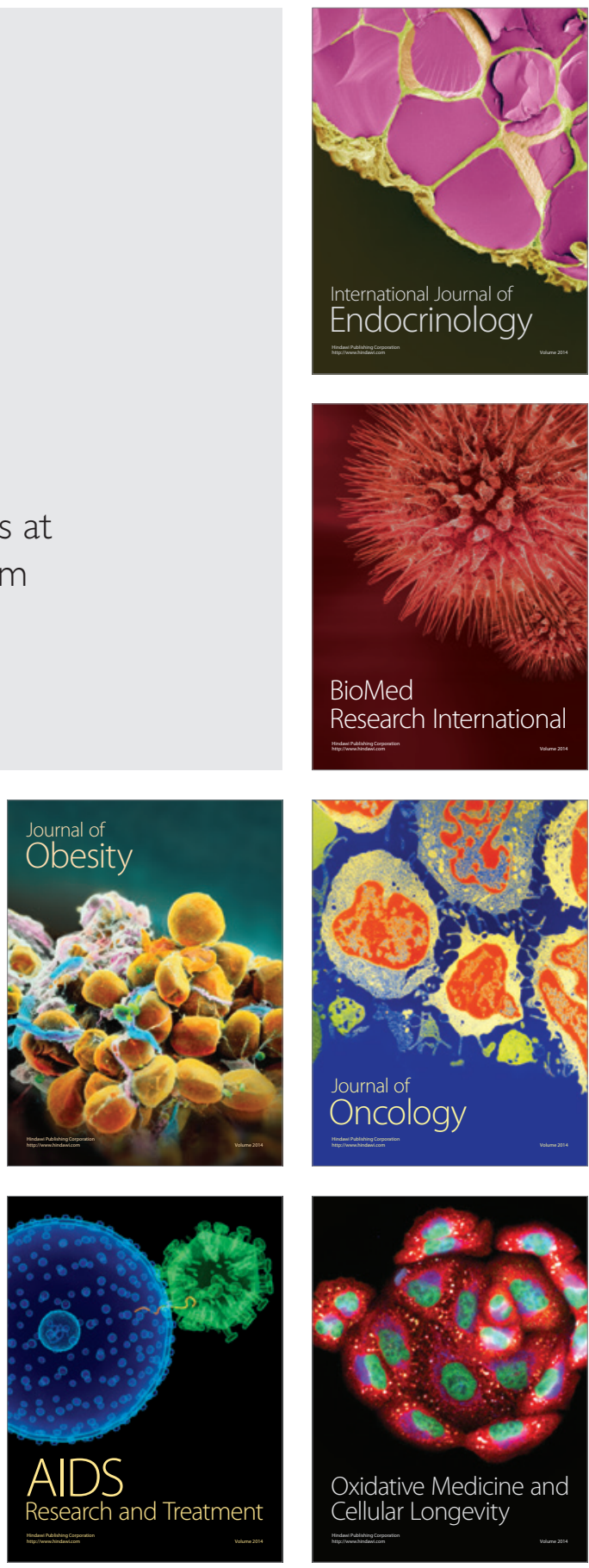